\title{
Effect of Student Participation in Business Center, Parent's Role, and Self-Efficiency to Entrepreneurship Intention Students of SMK
}

\author{
Andani Apriliana \\ Ery Tri Djatmika \\ Education Administration State University of Malang \\ e-mail: andaniapriliana@gmail.com
}

\begin{abstract}
The purpose of this research (1) condition of students' participation in the business center, parental role, self-efficacy, and student entrepreneur willingness, (2) influence of student participation in the business center, parental role, and self-efficacy partially to student entrepreneur willingness, (3) the influence of participation in the business center, parental role, and self-efficacy on student entrepreneurship willingness, and (4) difference entrepreneur willingness for the first year and second-year students. This study is a comparative causal and technique of collecting data using questionnaire. The result of this research (1) students' participation in Business Center have high categorized and positively and significantly influence to willingness, (2) parental role is a very high categorical student and have the positive and significant influence to student entrepreneurship willingness, (3) self-efficacy of the high categorized student, but not positively and significantly influence to intent entrepreneurship, (4) willingness of entrepreneurship is very high categorize, (5) students' participation in Business Center and parental role simultaneously has positively and significantly influence on willingness, (6) there is a difference of willingness of student entrepreneur for the first year students with second year students, (7) there is no difference in student participation in Business Center for the first year and second year students, (8) there is a difference of parental role of first year and second year students, and (9) there no difference of self-efficacy for the first year with second year students.
\end{abstract}

Keywords: Participation at Business Center, Parental Role, Self-Efficacy, Entrepreneurship Willingness

The level of work competition in Indonesia is increasingly tight, forcing someone to add new jobs. One of the things they need is to become an entrepreneur, but now an entrepreneur in Indonesia is a little bit. As explained by the Central Board of the Indonesian Young Entrepreneurs Association (BPP HPMI) Bahlil Lahadalia through Suara.com, that entrepreneurs in Indonesia amount to 1.5 percent of about 252 Indonesians, and still need about 1.7 million employers to increase entrepreneurship to two percent. Indonesia ranks fifth after Vietnam with 3.3 percent entrepreneurship in ASEAN.

An entrepreneur is someone who does the job by creating a creative and innovative idea to get the maximum benefit. The above opinion is supported by the opinion of Suryana (2013: 13) that the entrepreneur is someone who has the ability to use and combine existing resources to achieve the desired goals. Another opinion about entrepreneurship is that people take risks from one job to another by choosing different benefits and risks (Hendro, 2011: 23).

To become a professional entrepreneur requires intense in entrepreneurship. The intention is "intention that comes from within a person who 
will then encourage him to perform a real action" (Janah, 2015: 215). Sedangan for the intention of entrepreneurship is "desire/intention that exists in a person to perform an entrepreneurial action" (Wijaya in Janah, 2015: 214). Education as a container or a primary place in building professional human resources, very important role in sharpening the skills of human resources. Vocational High School (SMK) is one of the educational institutions that perform production-based learning process and produce graduates who are competent in their field, and able to go directly to create or become a superior workforce in the field. According to Heny (2012: 124) the purpose of vocational school are (1) preparing students to enter the work world, (2) students able to develop themselves, (3) fill the needs of business and industry, and (4) SMK graduates are graduates who have provisions in the world of work.

SMK as a formal education that provides more facilities in improving student entrepreneurial intentions, must be right on target and really give an important impression for students who implement or use the facility. One of the existing facilities in SMK, especially SMK Management in order to improve the intention of entrepreneurship is Business Center. Business Center is a kind of alfamart / indomart mini market, but in schools especially SMK Manajemen. SMK students practice direct sales at the Business Center by becoming salespeople at the Business Center, for example, the practice of displaying merchandise, being a cashier, and others. This will work with the support of families, especially parents. The role of parents is one of the factors that influence students' entrepreneurship intentions apart from their participation in the Business Center. Parents as the first person known to the child, and giving the child a first-time education, should be a good role for the child. Mahoney, Parente and Zigler in Santrock (2014: 90) say whether children participate in an activity at school, strongly influenced by the extent to which parents support and encourage their participation. Another suggestion is that children early on have been educated and motivated to make their parents' work their job choice in the future (Naffziger in Maulida \& Dhania, 2012: 3). Furthermore, the role of parents is to advise, motivate, encourage, and as facilitator for children in making a decision.

After the parents direct and encourage the child in making a decision, then the child himself must make the decision. Decision making done by children is also called self-efficacy (self-efficacy). According to Bandura in Janah (2012: 215) "Selfefficacy is a strong personal belief in the skill and ability to start a task and lead it to success". As mentioned earlier that intention means determination, in a large English dictionary called Intention which means intention or will. Suryana (2013: 80) states "will is a determination or a strong intention and high motivation". Another opinion of Farouk and Ikram (2014: 48) "the intention is the cognitive demonstration of the will of a person to exercise a behaviour". The intention is the intention of performing an action or behaviour in the will.

Hisrich, Peters, and Shepherd (2008: 74) say that "entrepreneurial intentions are motivational factors that influence individuals to pursue results in entrepreneurship". The indicators of the intention of entrepreneurship according to Malebana (2014: 1021) namely attitude, subjective norms, and behaviour control. Participation comes from the English language "participation" which means the participation. Participation in Big Indonesian Dictionary is action in taking part or 
participation. According to Isbandi in Deviyanti (2013: 383) that participation is the participation of a person in making a decision whether it is a solution to solve a problem, an effort in dealing with a problem, and an evaluation of the current situation.

Business Center in the school is a marketing laboratory wherein it there are buying and selling activities of various general necessities to meet daily needs and managers are students assisted by teachers as a director. Wardani (2015: 528) argues that "Business Center is a place for the provision of goods of general needs and needs for the students". The purpose of the Business Center is to train students 'entrepreneurship skills and intentions so that students after graduation will be able to work independently and become leaders for themselves, increasing students' creativity in honing their skills in entrepreneurship, communication skills, and developing ideas that are still buried within students. The indicators of participation by Deviyanti (2013: 382) are real participation (energy, money, property) and unreal participation (ideas, thoughts).

The role of parents is an important factor for children who will be adulthood. Ardianto (2011: 173) says that the key to success of children is in the role of fathermother which they are who develop children's success character. Good parent roles are those who always pay attention to their children lovingly, become facilitators for children, provide constructive motivation for children, encourage children to move forward. In school activities, parents also have to contribute in determining the activities of children. According to Epstein in Santrock (2014: 86) "almost every parent's family plays an important role in supporting and encouraging children's achievement and attitude toward school". The indicators of the role of parents according to Hernandez, et al (2013: 154) of support, a sense of love and affection. Self-efficacy (Self-Efficacy) is one of the factors that influence the child in taking a decision. Self-efficacy originates within oneself in discovering his beliefs. Santrock (2007: 265) "self-efficacy is a belief in the ability of self to master a situation and produce a cool end". The indicator of self-efficacy according to Bandura (1994: 4) is the process of cognitive and affective processes.

Research conducted by Prabandari and Rashid (2015: 9) states that entrepreneurial learning through Business Center has a positive and significant impact on student entrepreneurship intentions. In the study stated that the better entrepreneurial learning in Business Center will be higher also the intention of student entrepreneurship. Similarly, in Jusmin's research (2012: 149) that the relationship of practical activities in school units with entrepreneurial intentions have a positive effect. The better the practical activities are undertaken in the production unit, the more increasing student entrepreneur intentions. Wardani (2015: 533) argued in his research that the liveliness of students in the Business Center has a significant effect on student entrepreneurship intentions. The same is also reinforced by the results of research which states the practice experience has a positive and significant impact on the intention of entrepreneurship (Farouk \& Ikram, 2014: 53).

Prabandari and Rasyid (2015: 8) suggested the results of research that the family background positively and significantly influences the competence of student entrepreneurship. Another opinion of research conducted by Maulida and Dhania (2012: 5) that support parents have a positive effect on student entrepreneurship 
intentions. The higher the support provided by the parents will be higher also intense entrepreneurship. Evaliana (2015: 67) suggests that the family environment shows that there is a significant positive effect on the variables intense entrepreneurship. The better the role of parents in supporting and educating the child will be the better interest of entrepreneurship students. A similar opinion was expressed by Wardani (2015: 533) in his research that the family environment had a partial and significant influence on the motivation of student entrepreneurship. The higher the role of the family environment in this study is the role of parents, the higher the students' entrepreneurship motivation is shown. The researcher further stated that family background influence partially and significant to entrepreneurial readiness (Jusmin, 2012: 147). Families are influential in the formation of students' readiness in entrepreneurship and play an important role in it. Different proposed by Ratumbuysang and Rashid (2015: 22) that in his research there is no significant influence or relationship between the role of parents with student entrepreneurship intentions, because the pattern of inappropriate parenting provided by parents as the formation of child character becomes a problem in research this.

Handaru et al (2014: 1054) put forward the results of his research that selfefficacy affects the intention of entrepreneurship. Children who practice entrepreneurship will learn more about business and continue to convince themselves to run it. Janah (2015: 219) in his research said that self-efficacy has a positive and significant impact on the intention of entrepreneurship. One's confidence in looking at the future, wanting to be someone who succeeds in encouraging him to believe in taking a decision. The next opinion raised by Evaliana (2015: 67) that the efficacy of self-affects positively and significantly to the variable intensity entrepreneurship. This means that the higher the self-efficacy of students the higher the intensity student entrepreneurship.

Maulida and Dhania (2012: 5) state that there is a positive relationship between selfconfidence with student entrepreneurship motivation. This shows that the higher the confidence hence the higher the motivation of student entrepreneurship. Similar research by Firmansyah, Djatmika, and Hermawan (2016: 50) states that the selfefficacy of entrepreneurship is positively and significantly related to the intention of entrepreneurship of business and management students. There is a simultaneous relationship between Student Participation in Business Center, Parent Role, and Self Efficacy of Student Entrepreneur Intent. It can be said that student participation in the business centre, parent role, and self-efficacy is a factor influencing entrepreneurship intention seen from the influence of each independent variable to dependent variable. Previous research stated that family background, practical activities in school production units, and the implementation of learning together significantly influence the readiness of entrepreneurship (Jusmin, 2012: 148). In addition, there are also research results from Prabandari and Rashid (2015: 9) that entrepreneurial learning through Business Center, practice experience, and family background have a positive and significant impact on the competence of entrepreneurship of vocational students.

Intent entrepreneurship is needed for a person because not always someone can get a permanent job. Different intentions of entrepreneurship of each person are very different. The difference in the intentions of entrepreneurship is seen from the 
experience of working according to Indiarti and Rostiani (2008: 19) that someone who has experience working longer than the intention of entrepreneurship is higher than someone who just started working experience. Another opinion suggests that after attending entrepreneurship courses and carrying out its practices, 54 out of 61 students feel like to be entrepreneurs after 31 out of 61 students are hesitant to become entrepreneurs (Febriyanto, 2015: 121). Thus, it can be concluded that it is true that the practice of entrepreneurship carried out in the longer term will increase the intention of entrepreneurship.

\section{METHOD}

Independent variables in this research are participation in Business Center (X1), parent role (X2), and self-efficacy (X3) with the dependent variable of entrepreneurship intention (Y). This study is a comparative causal study with a population of 145 students from the first year and second year of marketing, sampling using proportionate random sampling calculated with slovin formula and obtained the number of samples of 106 students. The technique of collecting data using questionnaire with alternative answer 5 and documentation. Data analysis used is descriptive analysis, classical assumption test, multiple linear regression analysis, and test of independent difference of sample t-test. The design of this study is as follows.

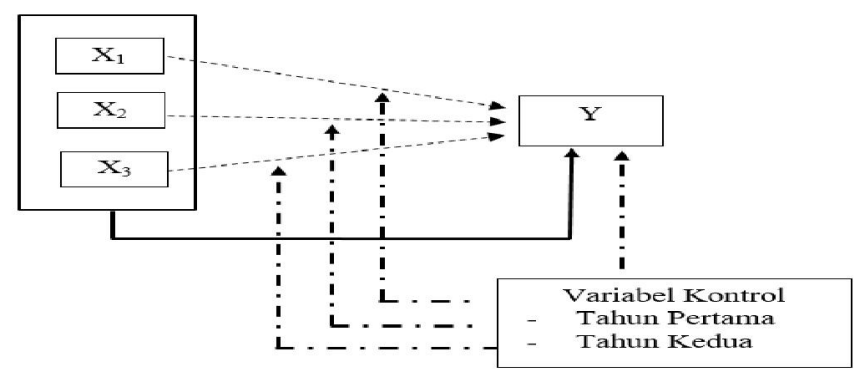

Figure 1 Research Design

\section{Information:}

\section{$=\quad=$ Influence simultaneously \\ = Partial influence \\ $-\cdot-\cdot-\cdot=$ Differences between variables \\ DISCUSSION \& RESULT}

The results of this study, the variables of participation in Business Center students most answered agree on 6 of 9 statements. The average respondent's answer to student participation variables in Business Center amounted to 3.684, thus the participation of students in the Business Center of the first year and the second year of marketing SMK Negeri 1 Pogalan is high. The role variables of the parents of the students mostly answered strongly agree on all statements which amounted to 8 statements. The average respondent answer of 4.728 so that the role of parents of the first year and the second year of marketing SMK Negeri 1 Pogalan is very high. Student self-efficacy variables largely answered agree on 7 of 8 statements. The 
average respondent answers 3,964 so that self-efficacy from the first year and second year of SMK Negeri 1 Pogala market is high. Variable intensity entrepreneurship some students answered strongly agree on 5 of 8 items. The average respondent answer of 8 items of the statement of intense entrepreneurship variable is 4,326, this means that first-year entrepreneur intent and second-year marketing department SMK Negeri 1 Pogalan is very high. The results of multiple linear regression analysis and the Independent Sample t-Test can be seen in the following table.

Table 1 Results of Multiple Linear Regression Analysis

\begin{tabular}{|c|c|c|c|c|c|}
\hline \multirow[t]{2}{*}{ Model } & \multirow{2}{*}{\multicolumn{3}{|c|}{$\begin{array}{c}\begin{array}{c}\text { Standard } \\
\text { ized } \\
\text { coefficie } \\
\text { nts }\end{array} \\
\text { Beta }\end{array}$}} & \multirow[t]{2}{*}{$\mathbf{t}$} & \multirow[t]{2}{*}{ Sig. } \\
\hline & & & & & \\
\hline 1 (Constants) & 3,692 & 6,096 & & 0,606 & 0,546 \\
\hline $\begin{array}{l}\text { Participation in } \\
\text { Business Center } \\
\text { (X1) }\end{array}$ & 0,286 & 0,062 & 0,389 & 4,595 & 0,000 \\
\hline Parent Role (X2) & 0,568 & 0,160 & 0,301 & 3,548 & 0,001 \\
\hline Self Efficacy (X3) & & & 0,198 & 1,962 & 0,052 \\
\hline \multicolumn{6}{|c|}{ Dependent variable : Intensi Entrepreneurship } \\
\hline$F_{\text {hitung }}$ & $: 19,74$ & & & & \\
\hline Sig. & $: 0,000$ & & & & \\
\hline $\mathrm{R}$ & $: 0,526$ & & & & \\
\hline R Square & $: 0,277$ & & & & \\
\hline Adjusted R Square & $: 0,263$ & & & & \\
\hline
\end{tabular}

Table 2 Independent Test Results Sample t-Test

\begin{tabular}{|c|c|c|c|c|c|c|}
\hline & & \multicolumn{2}{|c|}{$\begin{array}{c}\text { Test } \\
\text { Difference } \\
\text { Variance }\end{array}$} & \multicolumn{3}{|c|}{$\begin{array}{l}\text { Test the Average } \\
\text { Difference }\end{array}$} \\
\hline & & $\mathbf{F}$ & Sig. & $\mathbf{t}$ & df & Sig. \\
\hline \multirow[t]{3}{*}{ Value } & Differences Intensi & & & & & \\
\hline & $\begin{array}{l}\text { Entrepreneurship first } \\
\text { year students with a } \\
\text { second year }\end{array}$ & 1,176 & 0,281 & 2,459 & 104 & $\begin{array}{c}0,01 \\
6\end{array}$ \\
\hline & $\begin{array}{l}\text { Student Participation } \\
\text { Differences at Business } \\
\text { Center of first year } \\
\text { students with second year }\end{array}$ & 0,021 & 0,884 & $\begin{array}{c}- \\
0,036\end{array}$ & 104 & $\begin{array}{c}0,97 \\
1\end{array}$ \\
\hline
\end{tabular}




\begin{tabular}{lllllc}
\hline $\begin{array}{l}\text { Different Role of Parents of } \\
\text { the first year students with } \\
\text { the second year }\end{array}$ & 0,440 & 0,509 & $\begin{array}{c}- \\
2,579\end{array}$ & 104 & 0,01 \\
\hline $\begin{array}{l}\text { Differences in self-efficacy } \\
\text { first-year students with a } \\
\text { second year }\end{array}$ & 0,094 & 0,759 & $\begin{array}{c}- \\
1,546\end{array}$ & 104 & $\begin{array}{c}0,12 \\
5\end{array}$ \\
\hline
\end{tabular}

Source: Data (processed)

Result of hypothesis test: (1) student participation in the business center have positive and significant influence on student entrepreneur intention, (2) parent role have positive and significant influence to students entrepreneur intention, (3) self efficacy has no positive and significant influence (4) student participation in Business Center and parent role together to positively and significantly influence student entrepreneur intent, (5) first-year entrepreneurship intentions differ from the second year, (6) student participation in Business Center is no different from first year students with second, (7) the role of parents of first year students is different from the second year, and (8) self-efficacy of first year students is different from the second year.

\section{Student Participation in Business Center}

The result of the frequency distribution of student participation variable at Business Center is 3,684. This indicates that student participation in Business Center of the first year and second year of SMK Negeri 1 Pogalan is categorized high. This is supported by schools that manage facilities for students to practice entrepreneurship in school environment well. Business Center is the effort of the school to improve the ability of students in accordance with their respective areas of expertise. Students can practice directly into qualified entrepreneurs by implementing the practices at the Business Center.

Based on the results of the research, there is a positive and significant influence on the students' participation in the Business Center on the intention of first and second-year entrepreneurship of SMK Negeri 1 Pogalan. The existence of these influences can be concluded that participation in Business Center both high and low affect positively and significantly to improve the intention of entrepreneurship.

Students who participate in the Business Center often will have a high entrepreneurial spirit. Students will understand how to become an entrepreneur, understand how to manage the business properly, able to serve consumers well and politely, mastering ethics while working, and able to learn to be a leader in work.

The results showed that there is a positive and significant influence on students' participation in the Business Center on the intentions of entrepreneurship. This is similar to research from Prabandari and Rashid (2015: 9) which states that entrepreneurial learning through Business Center has a positive and significant impact on student entrepreneurship intentions. Another study from Jusmin (2012: 149) also suggests that the relationship of practical activities in school units with the intention of entrepreneurship positively influence.

The same thing was put forward by Wardani (2015: 533) in his research that student activeness in Business Center has significant effect on student entrepreneur 
intention. The same thing is also reinforced by the results of research that states the practice experiences have a positive and significant impact on the intentions of entrepreneurship (Farouk \& Ikram, 2014: 53). This means that the more frequent student participation in the Business Center will further enhance student entrepreneurship intentions.

The results of this study of student participation in Business Center first year with the second year is no different. There is no difference in participation in the Business Center in the first and second year because the participation in Business Center is very comprehensive for the first and second-year students. Each level gets their respective duties.

\section{The Role of Parents}

The result of the frequency distribution of parent role variable is 4,728. This means that the role of parents of first and second-year students SMK Negeri 1 Pogalan categorized very high. This is because parents are very concerned about all the activities of children, the pattern of care that is applied very well to make children very obedient and listen to every positive thing given by their parents.

The results of the study there is a positive and significant influence on the role of parents to the intention of entrepreneurship students of the first year and second year of SMK Negeri 1 Pogalan. The existence of these influences can be concluded that the high and low role of parents will affect positively and significantly in improving the intentions of entrepreneurship.

The higher the support provided by the parents will be higher also intense entrepreneurship. The result of this research is there is influence between parent role to student entrepreneur intention. This is similar to the research put forward by Prabandari and Rashid (2015: 8) that family backgrounds have a positive and significant impact on the competence of student entrepreneurship. Another opinion of research conducted by Maulida and Dhania (2012: 5) that support parents have a positive effect on student entrepreneurship intentions. Evaliana (2015: 67) suggests that the family environment shows there is a significant positive influence on the variables intense entrepreneurship. The better the role of parents in supporting and educating the child will be the better interest of entrepreneurship students.

A similar opinion was expressed by Wardani (2015: 533) in his research that the family environment had a partial and significant influence on the motivation of student entrepreneurship. Another similar study is from Jusmin (2012: 147) that family backgrounds influence partially and significantly to entrepreneurial readiness. In contrast to research from Ratumbuysang and Rashid (2015: 22) who argued that in his research there is no significant influence or relationship between the role of parents with student entrepreneurship intentions because the inappropriate parenting pattern given by parents as the formation of child character becomes a problem in the study.

The results of this study the role of parents of the first year with the second year has a difference. This difference is due to the higher grade level, the higher the parent role given to the child. The higher the grade level of the child, the child's responsibility towards a task will also be greater, indirectly the parents will be extra attention to the child and always reminded of the things that matter.

Self Efficacy 
The result of the frequency distribution of self-efficacy variable is 3,964. This means that the self-efficacy of first and second-year students SMK Negeri 1 Pogalan categorized high. This is because students have confidence in themselves able to reach all its goals with their own ability. Self-efficacy is one of the internal factors that a person possesses and determines his success in order to achieve all of his goals. With high self-efficacy, a person will have high thinking as well. Apart from thinking, a person also has a behaviour that suits his own efficacy is in accordance with his thoughts. What is done according to what is thought?

Based on this research there is no positive and significant influence between self-efficacy against the intention of entrepreneurship of first-year students and second year of SMK Negeri 1 Pogalan. The lack of influence of self-efficacy variables on the intention of entrepreneurship is due to lack of confidence in entrepreneurship. Students of SMK Negeri 1 Pogalan not yet convinced that after graduating will entrepreneurship, they mostly have the interest to continue their education to a higher level. Self-efficacy students SMK Negeri 1 High pogalan considered to grow other things or other factors outside the research is not to cultivate the intentions of entrepreneurship, because there are other variables that more influence it.

This research is different from the research conducted by Handaru et al (2014: 1054) who put forward the results of his research that the efficacy of selfaffects the intentions of entrepreneurship. Janah (2015: 219) in his research also conveyed that self-efficacy has a positive and significant influence on the intention of entrepreneurship. Similar research by Firmansyah, Djatmika, and Hermawan (2016: 50) states that the self-efficacy of entrepreneurship is positively and significantly related to the intention of entrepreneurship of business and management students. So it can be concluded the self-efficacy variables in this study is different from previous similar studies, and to grow self-efficacy against student entrepreneurship intentions should further increase again confidence in entrepreneurship. Students must instil confidence in their minds

\section{Intent of Student Entrepreneurship}

The result of the frequency distribution of entrepreneurship intention variable is 4,326 . This means that the intention of entrepreneurship first-year students and second-year marketing majors SMK Negeri 1 Pogalan categorized very high.

Based on this research, the intention of first-year entrepreneurship differs from the second year. This is similar to research by Indiarti and Rostiani (2008: 19) that someone who has experience working longer than the intention of entrepreneurship is higher than someone who just started working experience. Another opinion suggests that after attending entrepreneurship courses and carrying out its practices, 54 out of 61 students feel that they want to become entrepreneurs after 31 out of 61 students are hesitant to become entrepreneurs (Febriyanto, 2015: 121).

This means that in this study that the participation of students in the Business Center as entrepreneurial learning for students succeeded in improving the intention of entrepreneurship second-year students marketing SMK Negeri 1 Pogalan. For first-year students with less entrepreneurial intentions, this is because 
the time to participate in the Business Center is still short, they still have to explore more about entrepreneurship and further enhance their entrepreneurship intention by learning entrepreneurship apart from the school environment.

\section{CONCLUSION \& SUGGESTIONS}

\section{Conclusion}

Conclusions in this study that researchers can provide for the SMK Negeri 1 Pogalan is to continue to improve self-efficacy students in entrepreneurship by providing inputs about self-efficacy deeper.

\section{Suggestion}

For subsequent researchers to continue this study on a wider population and selfefficacy variables to be moderated variables in subsequent further studies.

\section{REFERENCES}

Ardianto, T. T. 2011. Developing Children's Success Character in the Cyber Era. Jogjakarta: Ar-Ruzz Media. (Indonesian Origin).

Bandura, A. 1994. Self-efficacy. In V. S. Ramachaudran (Ed.), Encyclopedia of human behaviour (Vol 4, pp. 71-81): 4. New York: Academic Press. (Reprinted in H. Friedman [Ed.], Encyclopedia of mental health. San Diego: Academic Press, 1998). (Indonesian Origin).

Deviyanti, D. 2013. Study About Community Participation in Development. eJournal Administrasi Negara, (Online), 1 (2): 382-383, (http://eJournal.an.fisipunmul.org), accessed November 15, 2016. (Indonesian Origin).

Evaliana, Y. 2015. The Effect of Self Efficacy and Family Environment on Students Entrepreneurship Interest. Journal of Business and Management Education, (Online), 11 : 1 67, (http://journal.um.ac.id/index.php/jpbm/article/download/5034/1796), accessed 29 November 2016. (Indonesian Origin).

Farouk, A., \& Ikram, A. 2014. The Influence of Individual Factors on the Entrepreneurial Intention. International Journal of Managing Value and Supply Chains, (Online), 5 (4): 48-53, (http://airccse.org/journal/mvsc/papers/5414ijmvsc04.pdf), accessed November 20, 2016.

Febriyanto. 2015. Analysis of Differences in Interest in Entrepreneurship Before and After Enrolling Entrepreneurship Course. Journal Gentiaras Management and Accounting, (Online), 7 (2): (https://febriyanto79.files.wordpress.com/2015/02/penelitian-jurnalgema-juli-2015-analisis-minat-mahasiswa- entrepreneurship-before-and- 
after-taking-college-entrepreneurship.pdf), accessed February 21, 2017. (Indonesian Origin)

Firmansyah, A. H., Djatmika, E. T., \& Hermawan, A. 2016. The Effects of Adversity Quotient and Entrepreneurial Self-Efficacy on Entrepreneurial Intention Through Entrepreneurial Attitude. Journal of Business and Management, (Online), 18 (1): 48-50, (www.iosjournals.org), accessed November 21, 2016.

Handaru, A. W., Paramita, W., Achmad, A., \& Nandiswara, C. 2014. Influence of Attitudes, Subjective Norms, and Self-Efficacy of Intellectual Entrepreneurship. Journal of Paramadina University, (Online), 11 (2): 1054, (http://journal.paramadina.ac.id/index.php/upm/article/view/21), accessed November 14, 2016. (Indonesian Origin) .

Hendro. 2010. The Basics of Entrepreneurship: A Guide for Students to Know, Understand and Enter the Business World. Jakarta: Erland. (Indonesian Origin).

Hernandez, L., Gonzales, M., Bermudez, G., \& Alcazar, R. J. 2013. Parental Practices Scale for Children. Enero Junio, (Online), 22 (01): 154-155, (http://www.sciencedirect.com/science/article/pii/S0890856709658147), accessed December 28, 2016.

Hisrich, R. D., Peters, M. P., \& Shepherd, D. A. 2008. Entrepreneurship (Entrepreneurship). The 7th edition of Chriswan Sungkono \& Diana Angelica. Jakarta: Salemba Four.

Indiarti, N., \& Rostiani, R. 2008. The intent of Student Entrepreneurship: Comparative Study Between Indonesia, Japan, and Norway. Jurnal Ekonomika dan Bisnis Indonesia, (Online), 23 (4): 19, (https://nurulindarti.files.wordpress.com/2009/03/indarti-rostiani-jebi2008), accessed October 28, 2016. (Indonesian Origin).

Janah, W. 0. 2015. Experience of Industrial Practice, Achievement Motivation, and Self-Confidence (Self Efficacy) on Students Entrepreneur Intention. Journal of Business and Management Education, (Online), 1 (3): 214-219, (http://journal.um.ac.id/index.php/jpbm), accessed November 5, 2016. (Indonesian Origin).

Jusmin, E. 2012. Influence of Family Background, Practical Activity, and Implementation of Entrepreneurship Learning to Readiness of Entrepreneurship. Jurnal Kependidikan, (Online), 42 (2): 147-149, (http://journal.uny.ac.id/index.php/jptk/article/viewFile/3339), accessed November 15, 2016. (Indonesian Origin).

Malebana, M.J. 2014. The Effects of Knowledge of Entrepreneurial Support on Entrepreneurial Intention. Mediterranean Journal of Social Sciences, 
(Online),

(http://www.mcser.org/journal/index.php/mjss/article/download/3831/ 3748), accessed December 23, 2016.

Maulida, S. R., \& Dhania, D. R. 2012. The relationship between Self Confidence and People's Support Tuadengan Entrepreneurial Motivation. Journal of $\begin{array}{llll}\text { Psychology UNDIP, (Online), } 11 & \text { (2): }\end{array}$ (http://ejournal.undip.ac.id/index.php/psikologi/article/view/6630), accessed November 14, 2016. (Indonesian Origin).

Prabandari, E. T., \& Rashid, A. A. 2015. The Influence of Entrepreneurship Learning through Business Center, Prakerin, and Family Background to Entrepreneurship Competence. Journal of Vocational Education, (Online), 5 (1): 8-9, (http://journal.uny.ac.id/index.php/jpv/article/viewFile/6054/5239), accessed November 14, 2016. (Indonesian Origin).

Ratumbuysang, M. F.N. G. \& Rashid, A. A. The Roles of Parents, Environments, and Entrepreneurship Learning on Entrepreneurship Readiness. Journal of Vocational Education, (Online), 5 (1): 22, (http://journal.uny.ac.id/index.php/jpv/article/view/6058), accessed November 14, 2016. Indonesian Origin).

Santrock, J. W. 2007. Child Development. Volume 2. Eleventh Edition. Translation Mila Rachmawati and Anna Kuswanti. 2007. Jakarta: Erland. (Indonesian Origin).

Santrock, J. W. 2014. Educational Psychology. Book 1.

Wardani, K. P. 2015. The Influence of Learning Achievement, Family Environment, and Student Activity in Business Center on Student Entrepreneurship Motivation. Economic Education Analysis Journal, (Online), 4 (2): 528-533, (http://journal.unnes.ac.id/sju/index.php/eeaj), accessed 1 November 2016. (Indonesian Origin). 